\title{
Effects of the infusion of non-selective $\beta$-, and selective $\beta 1$ - or $\beta 2$-adrenergic agonists, on body fat mobilisation in underfed or overfed non-pregnant heifers
}

\author{
Anne Ferlay*, Yves Chilliard \\ Laboratoire sous-nutrition des ruminants, Inra, Theix, 63122 Saint-Genès-Champanelle, France
}

(Received 28 January 1999; accepted 25 May 1999)

\begin{abstract}
The aim of this study was to analyse the effects of the intravenous infusion of a non-selective $\beta$-agonist ( $\beta$-A) (isoproterenol, ISO), and selective $\beta 1$-A (dobutamine, D) or $\beta 2$-A (terbutaline, T) on body fat mobilisation in non-pregnant heifers, in a $2 \times 2$ crossover design with two treatments (underfeeding or overfeeding) and two periods. The effect of the duration of submission to each energy level on basal and ISO-induced fat mobilisation was also studied. ISO had a high and significant lipolytic effect whatever the energy level. Nevertheless, the response area of non-esterified fatty acids (NEFA) to ISO in underfed cows was 1.7 times greater than that in overfed cows. T had a slight but significant lipolytic effect on NEFA plasma response in the underfed group. D had no lipolytic effect. Basal and ISO-stimulated plasma NEFA levels were similar after 1 or 4 weeks of underfeeding. (C Inra/Elsevier, Paris.
\end{abstract}

heifers / isoproterenol / $\beta 1$ - and $\beta 2$-agonists / non-esterified fatty acids

Résumé - Effets de l'infusion d'un agoniste $\beta$-adrénergique non sélectif, d'un agoniste sélectif $\beta 1$ ou d'un agoniste sélectif $\beta 2$ sur la mobilisation des réserves lipidiques corporelles chez des génisses non gravides sous-nutries ou suralimentées. Les effets sur la mobilisation des réserves lipidiques corporelles d'un agoniste $\beta$ ( $\beta$-A)-adrénergique non sélectif (isoproterenol, ISO), d'un $\beta 1$ A (dobutamine, D) ou d'un $\beta 2$-A (terbutaline, T) sélectifs, infusés par voie intraveineuse, sont analysés chez des génisses non-gravides, selon un schéma croisé $2 \times 2$ avec deux traitements (sous-nutrition ou suralimentation) et deux périodes. L'effet de la durée pendant laquelle est appliqué chaque niveau énergétique sur la lipomobilisation basale ou stimulée par l'ISO est aussi étudié. L'ISO induit un effet lipolytique important et significatif quel que soit le niveau énergétique. Néanmoins, la surface de réponse des acides gras non-estérifiés (AGNE) à l'ISO, chez les vaches sous-nutries, est 1,7 fois plus élevée que celle obtenue chez les vaches suralimentées. T augmente légèrement, mais de manière significative, a réponse plasmatique des AGNE dans le groupe sous-nutri. D n'a pas d'effet significatif. Les teneurs, basale et stimulée par l'ISO, en AGNE plasmatiques sont similaires après une sousnutrition d'une ou de quatre semaines. $\mathcal{C}$ Inra/Elsevier, Paris.

génisses / isoprotérénol / agonistes $\beta 1$ - et $\beta 2$-adrénergiques / acides gras non-estérifiés

* Corresponding author

E-mail: ferlay@clermont.inra.fr 


\section{INTRODUCTION}

Animals mobilise their body reserves as fuel for other tissues during underfeeding. Adipose tissue (AT) is the major energy reserve of the body, and the mobilisation of AT triacylglycerols plays an important role in adapting to energy restrictions [15]. This is made possible by an increase in lipolysis, which depends mainly on catecholamines. Relative actions of catecholamines through the systemic circulation or the sympathetic nervous system are not fully resolved. The stimulation of $\beta$-adrenoceptors $(\beta-A R)$ or $\alpha 2-A R$ by catecholamines enhances or inhibits (respectively) the hormone-sensitive lipase, the enzyme which catalyses the breakdown of triglycerides into fatty acids and glycerol.

There are discrepancies in the literature about the expression of different sub-types of $\beta$-AR in bovine AT. The mRNA levels of $\beta 2$ - and $\beta 3$ - and predominantly $\beta 1$-AR subclasses are expressed in calf perirenal AT [11]. Data from binding studies indicate the presence of $\beta 1$ - and $\beta 2-A R$ in calf subcutaneous AT, although a high concentration of CGP12177, a selective $\beta 3$-agonist ( $\beta 3$-A), had no lipolytic effect [43]. Nevertheless, it now seems that this compound is an inadequate tool for demonstrating the presence of $\beta 3$-AR [23]. According to the results of another binding study [41], perirenal adipocyte membranes from heifers have $\beta 2$-, but not $\beta 1-A R$. In this study, however, the partial inhibition, by $\beta 1$ - as well as $\beta 2$-antagonists, of the increase in cAMP after isoproterenol (ISO, a non-selective $\beta$-A) stimulation, suggests a role for both $\beta 1$ - and $\beta 2-A R$. Futhermore, there was no measurement of in vivo or in vitro lipolytic responses in the majority of the studies on $\beta$-AR.

In a preliminary trial [19], we established the dose-response curves for the lipolytic effects of $\beta-, \beta 1$ - and $\beta 2-A$ on plasma NEFA concentration in underfed cows, showing a selective stimulation by $\beta 2-A$, but not by $\beta 1-A$ or only at high doses.
It is well established that the fasting [7, 22] or underfeeding $[16,21]$ of cattle increases the response of body fat mobilisation to catecholamines or non-selective $\beta$-A (ISO). In contrast, there is no published data on the effects of underfeeding or overfeeding on the in vivo responses to $\beta 1$ - or $\beta 2-\mathrm{A}$ in ruminants. Moreover, the adaptation of basal or stimulated fat mobilisation can vary with the length of the underfeeding period in ruminants. In the medium term (several weeks), underfeeding rapidly enhances the basal plasma NEFA levels up to a plateau [15]. This plateauing may be due to a mechanism aimed at saving body lipids (making it possible to prolong the survival of the animal) and/or limit the toxic effects of high NEFA concentrations [14]. There is, however, no data on the time-scale of the adaptation of fat mobilisation response to catecholamines in ruminants.

The two main aims of the present trial were to confirm our preliminary results concerning the effects of $\beta$-, $\beta 1$ - or $\beta 2$-A on fat mobilisation, and to analyse the adaptation of $\beta 1$ - and $\beta 2$-adrenergic lipolytic responses according to changes in energy levels (underfeeding versus overfeeding). The third objective was to analyse the time-scale of the adaptation of the $\beta$-adrenergic lipolytic response for a period of 4 weeks after a change in the food energy level.

We simultaneously monitored changes in plasma metabolites (glucose, lactate and 3-hydroxybutyrate $(\beta-\mathrm{OH}))$ and insulin, since variations in their concentrations could interact with the lipolytic response.

\section{MATERIALS AND METHODS}

\subsection{Animals and diets}

Four non-pregnant non-lactating Holstein $x$ Friesian heifers (body weight $571 \pm 33 \mathrm{~kg}$, body condition score $3.8 \pm 0.4$ on a $0-5$ scale, and $30-34$ months old) were used in a $2 \times 2$ crossover experimental design with two treatments (underfeeding or overfeeding, at $58 \%$ (low) or $135 \%$ (high) of maintenance energy requirements, 
MER) and two time periods. Treatment periods were for 28 days, preceded by a 15 -day preexperimental period and followed by a 15 -day post-experimental period. During pre- and postexperimental periods, animals were fed $85 \%$ (medium) of MER. The diets were calculated [27] from body weight at the beginning of the experiment so that the cumulative energy supply approximately covered ( $92 \%)$ the maintenance requirement during both the pre-experimental and post-experimental periods. Animals were housed in tie stalls under a 12-h light regime.

The diet for the underfed animals consisted of $58 \%$ hay, $13 \%$ pelleted barley and $29 \%$ soybean meal. The diet for the overfed animals consisted of $40 \%$ hay and $60 \%$ pelleted barley. The medium diet consisted of $55 \%$ hay, $38 \%$ pelleted barley and $7 \%$ soybean meal. Water was provided ad libitum. All heifers received $100 \mathrm{~g}$ of a mineral-vitamin premix daily. All rations were calculated [27] so that protein intake was similar and covered 123-124\% of the requirement (assumed to be $3.25 \mathrm{~g}$ of PDI $\cdot \mathrm{kg}^{-1}$ of body weight $^{0.75}$ ) of digestible protein in the intestine (PDI). The total mixed diet was offered at 11.30 hours. Feed refusals were determined daily during the experimental periods. Digestibility coefficients of organic matter, neutral detergent fibre and acid detergent fibre were determined for each heifer from 5-day pooled samples (total collection of faeces) during days 24-28 of each experimental period. The net energy (NE) intake was estimated according to Inra [27]. The energy requirement for maintenance was assumed to be $0.32 \mathrm{Mcal} \mathrm{NE} \cdot \mathrm{kg}^{-1}$ of body weight ${ }^{0.75}$. NE balance was calculated by subtracting the maintenance requirement from the intake.

\subsection{Adrenergic challenges}

\subsubsection{Injection of a non-selective $\beta$-adrenergic agonist}

ISO (Isuprel, Sanofi Winthrop Industrie, France, $4 \mathrm{nmol} \cdot \mathrm{kg}^{-1}$ body weight) was injected via the jugular vein on day 11 of the pre-experimental period, on days 4, 11 and 25 of the experimental period and on days 4 and 11 of the postexperimental period. Each challenge was administered at 10.00 hours. Blood samples were collected at -5 and +10 min from the time of injection.

\subsubsection{Infusion of non-selective $\beta$-, and selective $\beta 1$ - or $\beta 2$-adrenergic agonists}

Adrenergic infusions were administered on days 18-21 of each experimental period. The sequences of the four 60-min daily infusions were randomised across periods and groups, with one $\beta$-A (or placebo) per day. Catheters were implanted in the two jugular veins on the evening before the start of the 4-day infusion periods. Catheters were kept functional by flushing with $2 \mathrm{~mL}$ of sterile heparinised (1\%) saline. Challenges consisted of $60-\mathrm{min}$ infusions of ISO $\left(0.067 \mathrm{nmol} \cdot \mathrm{kg}^{-1}\right.$ body weight $\left.\cdot \mathrm{min}^{-1}\right)$, dobutamine (D, a selective $\beta 1$-A, Dobutrex, Lilly France SA, France, $1.5 \mathrm{nmol} \cdot \mathrm{kg}^{-1}$ body weight $\cdot \mathrm{min}^{-1}$ ), terbutaline ( $\mathrm{T}$, a selective $\beta 2-\mathrm{A}$, Bricanyl, Laboratoires Astra, France, $0.067 \mathrm{nmol} \cdot \mathrm{kg}^{-1}$ body weight $\cdot \mathrm{min}^{-1}$ ) or placebo (40-mL sterile saline) at a rate of $0.67 \mathrm{~mL} \cdot \mathrm{min}^{-1}$.

$D$ was chosen for its selectivity of $\beta 1-A R$ and for its lipolytic effect in rats and humans [8]. The other available $\beta 1-A, T-0509$, is not used in biological assays because the antagonism of its lipolytic effects suggests that it activates lipolysis via an additional non- $\beta$-adrenergic pathway [8]. Moreover, xamoterol, another $\beta 1-\mathrm{A}$, is known to be only partially $\beta 1$-selective [24]. The dose of $D$ was chosen because a previous trial showed that plasma NEFA did not respond to D infusion below $1.0-1.5 \mathrm{nmol} \cdot \mathrm{kg}^{-1}$ body weight $\cdot \mathrm{min}^{-1}$ in the underfed cows [19]

Although clenbuterol had lipolytic effects in ruminants $[3,6]$, it was not used because its selectivity for $\beta 2$-AR is still being debated [31]. $T$ was chosen for its $\beta 2$-selectivity and for its lipolytic action in humans [1]. ISO and T were infused (or injected, ISO) at equimolar doses, chosen according to $[19,20]$.

Each agonist was dissolved immediately before infusion in sterile $0.9 \% \mathrm{NaCl}$. Infusions started at 09.30 hours each day. Blood samples $(10 \mathrm{~mL})$ were obtained from the contralateral vein at $-20,-10,-5,10,20,30,45,60,80,100$ and $120 \mathrm{~min}$ from the start of the 60 -min infusion. Blood samples were collected in tubes containing EDTA ( $\left.2.1 \mathrm{mg} \cdot \mathrm{mL}^{-1}\right)$ and centrifuged at $3000 \mathrm{~g}$ for $20 \mathrm{~min}$ at $4{ }^{\circ} \mathrm{C}$. Plasma samples were frozen at $-20^{\circ} \mathrm{C}$ until analysis for insulin, NEFA, glycerol, glucose, L-lactate and $\beta-\mathrm{OH}$ using a multianalyser (Elan, Merck-Clevenot, Nogent-surMarne, France). Insulin was measured only in blood samples collected at $-20,+20,+45$ and $+80 \mathrm{~min}$ from the start of infusion. Insulin was determined by RIA (Insik-1 M kit, Oris Industry, 
Gif-sur-Yvette, France) with a sensitivity of $20 \mathrm{pmol} \cdot \mathrm{L}^{-1}$. The intra- and inter-assay $\mathrm{CV}$ were 9 and $13 \%$, respectively.

The intra-assay coefficient of variation (CV) for each metabolite determination was calculated using duplicate determinations on 570 samples taken from our trial. The inter-assay CV values for metabolite determinations were calculated from repeated measurements made on two control plasmas. These plasmas were taken from three dry non-pregnant adult cows that were either well-fed ( $\mathrm{F}$ control) or restricted to $17 \%$ of maintenance energy requirements for 7 days. Blood was taken from restricted cows $10 \mathrm{~min}$ after an injection of ISO (4 nmol $\mathrm{kg}^{-1}$ body weight) (RI control). The inter-assay $\mathrm{CV}$ $(n=12)$ was calculated from the mean values of six replicated determinations from 12 different days on $\mathrm{F}$ and RI control plasmas. The mean values of control plasmas were used to correct the experimental plasmas for inter-assay variations.

The NEFA concentration was determined using an enzymatic kit (C-test Wako, Unipath, Dardilly, France), previously calibrated by Chilliard et al. [12]. The intra-assay CV for NEFA was $0.5 \%\left(S D=0.003 \mathrm{mmol} \cdot \mathrm{L}^{-1}\right)$. The inter-assay CV for NEFA was $7 \%$ (pooled $\mathrm{SD}=0.057 \mathrm{mmol} \cdot \mathrm{L}^{-1}$, the means and SD of $\mathrm{F}$ and RI controls were $0.058 \pm 0.009$ and $1.676 \pm$ $0.079 \mathrm{mmol} \cdot \mathrm{L}^{-1}$, respectively).

Free glycerol was determined according to the glycerol kinase method [34] and a commercial kit (Sigma, France, reference 37-A). The intra-assay CV for glycerol was $1.7 \%$ (SD $\left.=1.26 \mu \mathrm{mol} \cdot \mathrm{L}^{-1}\right)$ and the inter-assay $\mathrm{CV}$ was $4 \%$ (pooled $\mathrm{SD}=3.79 \mu \mathrm{mol} / \mathrm{L}$, the means of $\mathrm{F}$ and RI controls were $4.97 \pm 1.25$ and $197.64 \pm$ $5.21 \mu \mathrm{mol} \cdot \mathrm{L}^{-1}$, respectively).

Glucose concentration was determined according to the glucose dehydrogenase method [5] and a commercial kit (Merck-Clevenot, Nogent-sur-Marne, France, reference 12193). The intra-assay $\mathrm{CV}$ for glucose was $0.5 \%(\mathrm{SD}=$ $\left.0.021 \mathrm{mmol} \cdot \mathrm{L}^{-1}\right)$ and the inter-assay $\mathrm{CV}$ was $2 \%$ (pooled SD $=0.087 \mathrm{mmol} \cdot \mathrm{L}^{-1}$, the means of $\mathrm{F}$ and RI controls were $3.912 \pm 0.092$ and $4.200 \pm$ $0.108 \mathrm{mmol} \cdot \mathrm{L}^{-1}$, respectively).

The L-lactate concentration was assayed with the lactate oxidase method [40] and a commercial kit (BioMérieux, Marcy-l'Etoile, France, reference 61192). The intra-assay CV for L-lactate was $0.5 \%\left(\mathrm{SD}=0.004 \mathrm{mmol} \cdot \mathrm{L}^{-1}\right)$ and the interassay $\mathrm{CV}$ was $8 \%$ (pooled $\mathrm{SD}=0.124 \mathrm{mmol} \cdot \mathrm{L}^{-1}$, the means of $F$ and RI controls were $0.745 \pm$ 0.173 and $2.389 \pm 0.025 \mathrm{mmol} \cdot \mathrm{L}^{-1}$, respectively).
The $\beta-\mathrm{OH}$ concentration was determined according to Barnouin et al. [4]. The intra-assay $\mathrm{CV}$ for $\beta-\mathrm{OH}$ was $4.1 \%\left(\mathrm{SD}=0.013 \mathrm{mmol} \cdot \mathrm{L}^{-1}\right)$ and the inter-assay $\mathrm{CV}$ was $4 \%$ (pooled $\mathrm{SD}=$ $0.021 \mathrm{mmol} \cdot \mathrm{L}^{-1}$, the means of $\mathrm{F}$ and RI controls were $0.426 \pm 0.023$ and $0.557 \pm 0.018 \mathrm{mmol} \cdot \mathrm{L}^{-1}$, respectively).

\subsection{Calculations and statistical analysis}

The overall change in blood metabolites during the 60-min infusions was estimated by calculating the area under the response curve and above the baseline (summation of the area between successive pairs of concentration-time coordinates). The baseline concentration was the concentration at $-5 \mathrm{~min}$ from the start of the infusion.

Data are expressed as means $\pm \mathrm{SD}$ and were analysed using the SAS GLM procedure [39]. For the data resulting from infusion protocols, the effects of the experimental period, the day of challenge nested within period and the cow were considered as random effects, whereas the effects of the animal group, and drug and energy levels were considered as fixed effects. The following model was used:

$$
\begin{aligned}
& Y_{i j k l m n}=\mu+P_{i}+(P \times D)_{i j}+G_{k}+(C \times G)_{k l}+E_{m} \\
& +(P \times C \times E)_{i l m}+\operatorname{drug}_{n}+(\operatorname{drug} \times E)_{m n}+e_{i j k l m n}
\end{aligned}
$$

where $\mu$ was the overall mean and the other terms were, respectively: period effect ( $1 \mathrm{df})$, day of challenge effect nested within period ( $3 \mathrm{df}$ ), group effect $(1 \mathrm{df})$, cow effect nested within group $(2 \mathrm{df})$, energy level effect $(1 \mathrm{df})$, period $\times$ cow $\times$ energy level interaction ( $2 \mathrm{df}$, error 1$)$, drug effect ( $3 \mathrm{df})$, drug $\times$ energy level interaction $(3 \mathrm{df})$ and the residual error $(12 \mathrm{df})$. The effect of energy levels was tested against error 1 . All the other terms were tested against the residual error. Differences between energy levels (low versus high) and drugs (placebo, ISO, D or T) were analysed using the least-square mean procedure [39]. Significance was declared at $P<0.05$.

To analyse the short- and medium-term effects of energy levels on plasma NEFA (figure 1), data resulting from injection protocols on day 11 of the pre-experimental period, on days 4,11 and 25 of the experimental period, and on days 4 and 11 of the post-experimental period were compared within or between low, medium and high energy levels, using the within-cow pairwise Student's $t$-test with a probability of $0.01,0.05$ or 0.10 . 


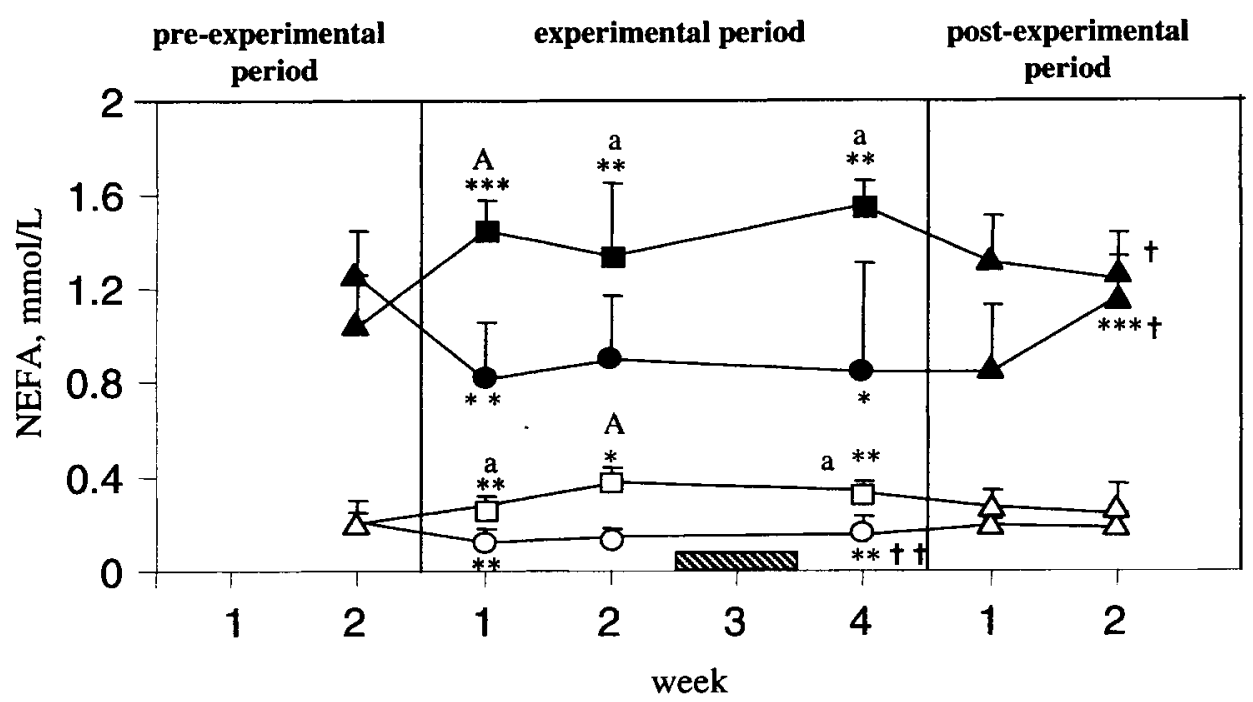

Figure 1. Effect of energy level on basal plasma non-esterified fatty acids (NEFA, open symbols), and plasma NEFA at $10 \mathrm{~min}$ (solid symbols) after the injection of non-selective $\beta$-agonist (isoproterenol, $4 \mathrm{nmol} \cdot \mathrm{kg}^{-1}$ body weight) in non-lactating, non-regnant heifers. Animals were fed at low ( or $\square$ ), medium $(\boldsymbol{\Lambda}$ or $\Delta$ ) or high $(\boldsymbol{O}$ or $\bigcirc$ ) energy level. *, **, or ***, values were significantly different from week 2 of the pre-experimental period, $P<0.10,0.05$ or 0.01 , respectively. $t$ or $\mathrm{ft}$, values were significantly different from week 1 of the experimental period, $P<0.10$ or 0.05 , respectively. a or A, the 'low' diet was significantly different from the 'high' diet, $P<0.10$ or 0.01 , respectively. All values at $10 \mathrm{~min}$ are significantly different $(P<0.01)$ from the basal value measured on the same day, whatever the diet, except for the 'high' diet at week 4 of the experimental period $(P<0.05)$ and for the 'medium' diet at week 1 of the post-experimental period $(P<0.05)$. $\$ 1 \mathrm{~W}$ Adrenergic infusions (see figure 2). Values are means \pm SD.

\section{RESULTS}

\subsection{Animals and diets}

Total dry matter intake was $2.7 \pm 0.1$ and $6.1 \pm 0.2 \mathrm{~kg}$ for under- and overfed heifers, respectively (table I). Organic matter digestibility did not differ between the two energy levels. In contrast, underfeeding significantly increased $(P<0.001)$ the neutral detergent fibre and acid detergent fibre digestibilities. The net energy balance of the underfed cows was negative, while that of the overfed cows was positive $(P<0.001)$.

The corrected body weight of the animals decreased or increased slightly during under- or overfeeding, respectively $(-3.6$ and $+1.4 \%, P<0.01$, table $I$ ).

\subsection{Effects of the feeding level and ISO injection on temporal changes in plasma metabolites and insulin}

A decrease in feeding levels (from medium to low energy level) over a period of 1 week enhanced basal $(P<0.05)$ and ISO-stimulated $(P<0.01)$ plasma NEFA (week 2 of the pre-experimental period versus week 1 of the experimental period, figure 1). The basal plasma NEFA was significantly higher after $2(P<0.10)$ and 4 $(P<0.05)$ weeks of underfeeding than at the end of the pre-experimental period. The stimulated fat mobilisation was significantly higher $(P<0.05)$ after 2 and 4 weeks of underfeeding than at the end of the preexperimental period. The basal and stimu- 
Table I. Ingredients, energy and protein intakes, organic matter, neutral detergent fibre and acid detergent fibre digestibilities of total mixed rations, energy balance and changes in body weight. ${ }^{1,2}$

\begin{tabular}{|c|c|c|c|}
\hline Nutritional status & $\begin{array}{l}\text { Underfed } \\
(n=4)\end{array}$ & $\begin{array}{c}\text { Overfed } \\
(n=4)\end{array}$ & Energy level effect \\
\hline \multicolumn{4}{|l|}{ Ingredient $\left(\mathrm{kg}\right.$ dry matter $\cdot$ day $\left.^{-1}\right)$} \\
\hline Hay & $1.53 \pm 0.08$ & $2.39 \pm 0.08$ & 0.001 \\
\hline Soybean meal & $0.75 \pm 0.05$ & - & 0.001 \\
\hline Barley & $0.35 \pm 0.00$ & $3.58 \pm 0.12$ & 0.001 \\
\hline Mineral and vitamin premix ${ }^{3}$ & $0.10 \pm 0.00$ & $0.10 \pm 0.00$ & NS \\
\hline Total feed & $2.73 \pm 0.13$ & $6.07 \pm 0.20$ & 0.001 \\
\hline \multicolumn{4}{|l|}{ Selected nutrient intake $\left(\mathrm{kg} \cdot \mathrm{day}^{-1}\right)$} \\
\hline OM & $2.44 \pm 0.12$ & $5.64 \pm 0.19$ & 0.001 \\
\hline PDI & $0.45 \pm 0.03$ & $0.47 \pm 0.02$ & NS \\
\hline \multicolumn{4}{|l|}{ Digestibility (\%) } \\
\hline OM & $77.5 \pm 1.4$ & $75.2 \pm 2.2$ & NS \\
\hline Neutral detergent fibre & $71.3 \pm 1.4$ & $55.6 \pm 5.9$ & 0.001 \\
\hline Acid detergent fibre & $65.3 \pm 2.1$ & $50.3 \pm 2.8$ & 0.001 \\
\hline Energy intake (MJ NE. day ${ }^{-1}$ ) & $17.2 \pm 0.9$ & $41.5 \pm 1.4$ & 0.001 \\
\hline Energy balance $^{4}\left(\mathrm{MJ} \mathrm{NE}^{- \text {day }^{-1}}\right)$ & $-12.5 \pm 0.8$ & $+10.6 \pm 0.2$ & 0.001 \\
\hline Variation in body weight $^{5}(\mathrm{~kg})$ & $-27 \pm 9$ & $13 \pm 6$ & 0.001 \\
\hline Variation in corrected body weight ${ }^{5,6}(\mathrm{~kg})$ & $-20 \pm 9$ & $8 \pm 6$ & 0.01 \\
\hline
\end{tabular}

I Values are means \pm SD. Number of observations (cows) in parentheses. NS: not significant $(P>0.05)$.

${ }^{2}$ Abbreviations used: OM, organic matter; PDI, protein digestible in the intestine (Inra, 1989); NE, net energy.

${ }^{3}$ Minerals, \%: P, 14; Ca, 16; Mg, 3; Na, 4.7. Trace elements, $\mathrm{mg} \cdot \mathrm{kg}^{-1}: \mathrm{Zn}, 4000 ; \mathrm{Mn}, 3000 ; \mathrm{Cu}, 800 ; \mathrm{I}, 60 ; \mathrm{Co}$, 20; Se, 5. Vitamins, $\mathrm{mg} \cdot \mathrm{kg}^{-1}$ : retinyl acetate, 86 ; cholecalciferol, $2 ; R R R$ - $\alpha$ tocopheryl acetate, 67.

${ }^{4}$ Balance $=$ intake-maintenance requirement.

${ }^{5}$ Variation between the 2 nd week of the pre-experimental period and the 4 th week of the experimental period.

${ }^{6}$ Corrected body weight $=$ body weight $-4 \times$ dry matter intake [13].

lated plasma NEFA levels after 4 weeks were no different from those determined after 1 week of underfeeding (figure 1 ).

An increase in feeding levels (from medium to high energy level) over a period of 1 week reduced the basal and ISO-stimulated plasma NEFA $(P<0.05$, week 2 of the pre-experimental period versus week 1 of the experimental period, figure 1). The basal $(P<0.05)$ or stimulated $(P<0.10)$ fat mobilisation was significantly lower only after 4 weeks of overfeeding than at the end of the pre-experimental period. The basal plasma NEFA level after 4 weeks was, however, slightly higher than that after 1 week of overfeeding $(P<0.05)$, whereas the stimulated NEFA level remained unchanged.
During the experimental period, the basal plasma NEFA in low diet cows was higher in weeks $2(P<0.01)$ and 1 or $4(P<0.10)$ than in high diet cows (figure 1). The stimulated plasma NEFA was higher in weeks 1 $(P<0.01)$ and 2 or $4(P<0.10)$ in underfed cows than in overfed cows (figure l).

Under basal conditions, both plasma NEFA $(P<0.05)$ and glycerol $(P<0.10)$ levels were higher in underfed than in overfed groups during the third week of the experimental period (table II). In contrast, the plasma concentration of lactate was decreased $(P<0.05)$ by underfeeding (figure 2). Plasma glucose, $\beta-\mathrm{OH}$ and insulin concentrations were not modified by energy levels (figure 2). 


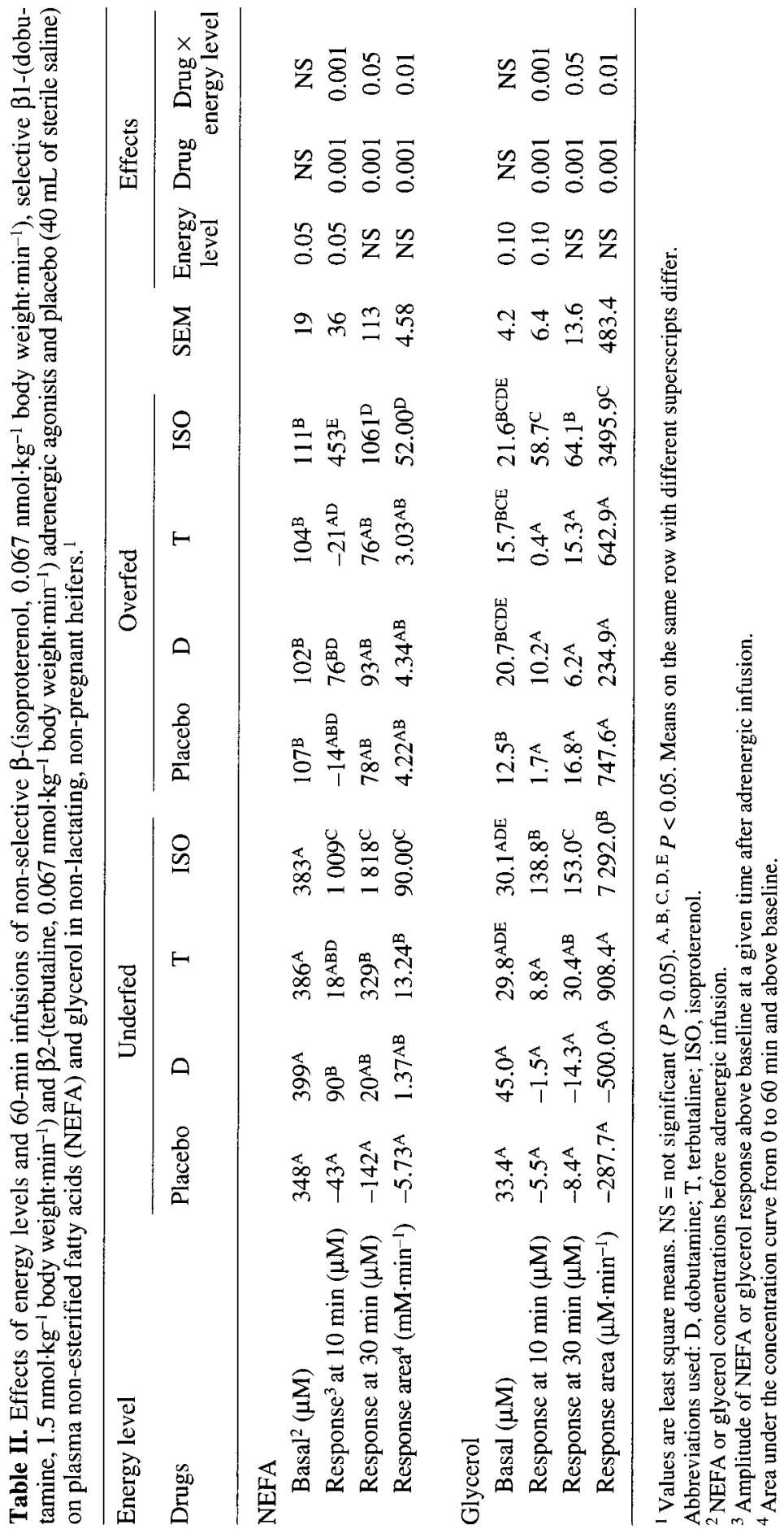



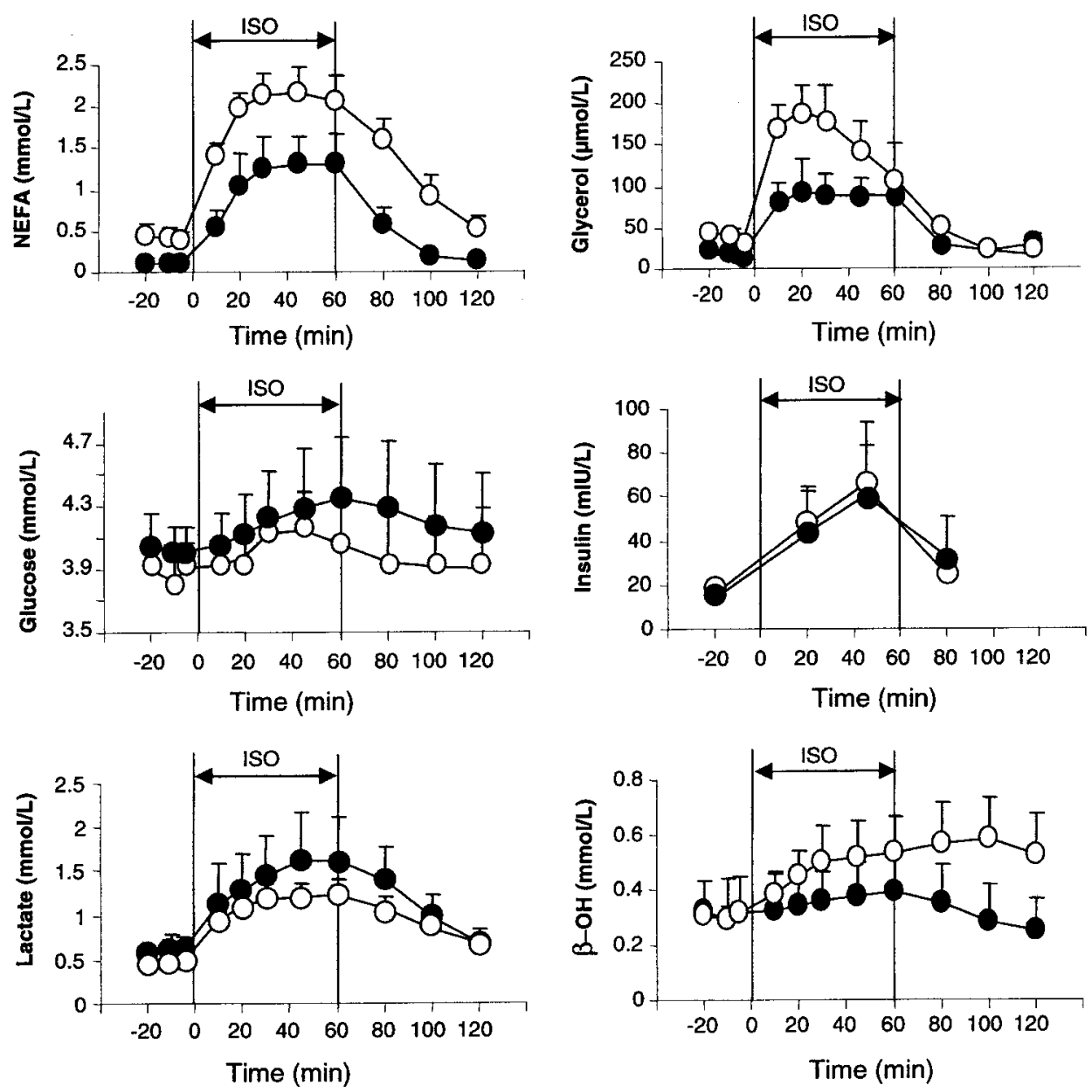

Figure 2. Effects of isoproterenol infusions $\left(0-60 \mathrm{~min}\right.$ at $0.067 \mathrm{nmol} \cdot \mathrm{kg}^{-1}$ body weight $\left.\cdot \mathrm{min}^{-1}\right)$ on plasma non-esterified fatty acids (NEFA), glycerol, glucose, insulin, lactate and 3-hydroxybutyrate $(\beta-O H)$ in underfed $(O)$ or overfed $(\bullet)$ non-pregnant, non-lactating heifers.

\subsection{Effects of the infusion} of non-selective adrenergic $\beta$-agonist, and selective $\beta 1$ - and $\beta 2$-adrenergic agonists, on plasma metabolites and insulin

The overall effects of the treatments are reported in table II. Both plasma NEFA and glycerol responses after $10 \mathrm{~min}$ of the drug infusions were significantly higher in under- fed than in overfed groups (table $I$ ). Drug effects were significant $(P<0.001)$ on plasma NEFA and glycerol responses at 10 and $30 \mathrm{~min}$, and on NEFA and glycerol response areas $(P<0.001)$. The interactions between drugs and energy level were significant for all variables (table $I I)$.

The plasma NEFA level during ISO infusion increased for $10 \mathrm{~min}$, and reached a plateau between 20 and $30 \mathrm{~min}$ for under- 
and overfed groups. The maximal NEFA concentrations at 45 and $60 \mathrm{~min}$ were 2.17 and $1.31 \mathrm{mmol} \cdot \mathrm{L}^{-1}(P<0.001)$, for underfed and overfed groups, respectively (figure 2 ). The glycerol level increased for $10 \mathrm{~min}$ for both groups, and peaked at 30 and $20 \mathrm{~min}$, at 189 and $94 \mu \mathrm{mol} \cdot \mathrm{L}^{-1}(P<0.01)$, for underfed and overfed groups, respectively. The concentrations of NEFA and glycerol returned to baseline values within 60 and $20 \mathrm{~min}$ after the end of ISO infusion, respectively (figure 2).

The $\mathrm{T}$ had a slight but significant effect on the plasma NEFA response at $30 \mathrm{~min}$ after the start of infusion in the underfed group $(P<0.05$, table $I I)$. The D had no lipolytic effect, except for the plasma NEFA response at $10 \mathrm{~min}$ in underfed cows $(P<0.05)$. ISO infusion induced the same trends in plasma NEFA and glycerol responses, but the response area of glycerol to $\beta$-A was markedly lower (approximately $12-15$ times) than that of NEFA.

ISO infusion enhanced glycaemia and insulinaemia $(P<0.05)$ whatever the diet (figure 2). Plasma glucose levels peaked at 45 and 60 min during ISO infusion for underfed and overfed cows, respectively. The maximal glucose concentrations tended to be lower $(P<0.10)$ in underfed cows than in overfed cows ( 4.15 versus $4.34 \mathrm{mmol} \cdot \mathrm{L}^{-1}$, respectively, figure 2). Glucose concentrations returned to the baseline within $20 \mathrm{~min}$ post-infusion in the underfed group, but not in the overfed group (figure 2). Plasma insulin peaked at $45 \mathrm{~min}$ for under- and overfed cows (66.4 versus $61.6 \mathrm{mIU} \cdot \mathrm{L}^{-1}$, respectively, figure 2). ISO sharply increased plasma lactate in underfed and overfed cows $(P<0.01$, figure 2$)$. The maximal concentration of plasma lactate tended to be lower $(P<0.10)$ in underfed cows than in overfed cows ( 1.200 versus $1.627 \mathrm{mmol} \cdot \mathrm{L}^{-1}$, respectively, figure 2). The lactate levels declined but did not return to the baseline after the end of ISO infusion. ISO increased plasma $\beta$-OH only in underfed cows $(P<0.05$, figure 2 ) and this effect lasted for at least
60 min after the end of the ISO infusion. T and $\mathrm{D}$ infusions did not modify any metabolite or insulin concentration, and the interactions between drug and energy levels were not significant (data not shown).

\section{DISCUSSION}

\subsection{Role of $\beta 1$ - and $\beta 2$-adrenergic agents in body fat mobilisation}

The absence of a lipolytic effect of $D$, whatever the energy level, corresponds to our previous data on underfed cows [19], showing a very small change in NEFA concentrations in animals infused with similar $\mathrm{D}$ doses. Both results seem to contradict the relatively high proportion of $\beta 1$-AR in the $\beta$-AR population of bovine AT ( $29 \%)$ [43]. $D$ is probably not very efficient as a $\beta 1-A$, as was shown in the pig [35]. In humans and rats [32], the presence and role of $\beta 1-A R$ were shown by binding studies and in vitro or in situ measurements of lipolytic responses stimulated by ISO and inhibited by selective $\beta 1$-antagonists (i.e. CGP120712) [1, 30, 33]. Further in vivo experiments using these tools will be necessary to better clarify the role of $\beta 1-A R$ in fat mobilisation of cattle.

ISO caused significant lipolytic effects as compared to the slight effects of $T$. This result is surprising, but confirms in part our previous data [19]. At the same infused dose $\left(0.07 \mathrm{nmol} \cdot \mathrm{kg}^{-1}\right.$ body weight $\left.\cdot \mathrm{min}^{-1}\right)$, the response area to $\mathrm{T}$ was only $49 \%$ of the response area to ISO in the previous study, and $15 \%$ of that in the present study. Similarly, the dialysate glycerol response area to $\mathrm{T}$, perfused in situ at $10^{-4}$ or $10^{-5} \mathrm{M}$ in underfed ewes, represented only 38 or $49 \%$, respectively, of the response to ISO [21].

In ruminants, only indirect comparisons can be made between the effects of $T$ and other $\beta 2-A$. Clenbuterol infusing [3] at $0.04 \mathrm{nmol} \cdot \mathrm{kg}^{-1}$ body weight $\cdot \mathrm{min}^{-1}$ for 60 min (half the dose of that of $T$ used in our study) in lactating well-fed cows increased the plasma NEFA up to levels 
similar to those obtained with $\mathrm{T}$ in our study. In contrast, $\mathrm{T}$ infusing at $0.03 \mathrm{nmol} \cdot \mathrm{kg}^{-1}$ body weight $\cdot \mathrm{min}^{-1}$ had no lipolytic effect in underfed cows [19]. Thus, clenbuterol seems to be more potent than $\mathrm{T}$, but less so than ISO, and this may be due in part to the fact that clenbuterol could interact with other $\beta$-AR (e.g. $\beta 1$-AR) [31].

The weak effect of $T$ could not be explained by a low number of $\beta 2$-AR in cattle AT, which is about $70 \%$ of the sum of $\beta 1-, \beta 2-$ and $\beta 3$-AR [43]. Our result could be due to a higher affinity or maximal activity of ISO than $T$ for the $\beta 2$-AR. Indeed, the in vitro $\mathrm{ED}_{50}$ of ISO and $\mathrm{T}$ in humans was approximately $3.10^{-9}$ and $10^{-7} \mathrm{M}$, respectively [1]. The in vitro maximal activity of T was 40 and $69 \%$ of the activity of ISO, in pigs [35] and in humans [1], respectively.

The high lipolytic effect of ISO could also be due to its interaction with other $\beta$ $\mathrm{AR}$, such as $\beta 3$ - or $\beta 4$-AR. Nevertheless, the in situ perfusion of a selective $\beta 3-A$ in subcutaneous AT of underfed ewes had no lipolytic effect [21]. Galitzky et al. [23] suggested the existence of $\beta 4-A R$ in human subcutaneous AT, but no data on putative $\beta 4-A R$ in ruminants are available.

The ISO infusion increased plasma $\beta-\mathrm{OH}$ and lactate concentrations (figure 2). The increase in plasma $\beta-\mathrm{OH}$ by a $\beta$ - $\mathrm{A}$, in the monogastric species, was shown to be due to an increase in the production of ketone bodies by the liver, combined with an increase in the plasma NEFA concentration [45]. $\beta-\mathrm{OH}$ may be antilipolytic in vivo in cattle [36], but this seems to be unlikely in our study because the maximal concentrations of $\beta-\mathrm{OH}\left(0.34-0.44 \mathrm{mmol} \cdot \mathrm{L}^{-1}\right)$ were much lower than those $\left(2-4 \mathrm{mmol} \cdot \mathrm{L}^{-1}\right)$ required for an antilipolytic effect.

The increase in plasma lactate during ISO infusion was probably caused essentially by muscle glycogenolysis resulting from the activation of $\beta 2$-AR [41]. Lactate could have an antilipolytic effect under basal conditions in vitro in the $\operatorname{dog}$ [17] or on ISO- induced lipolysis in human fat cells at very high concentrations $\left(16 \mathrm{mmol} \cdot \mathrm{L}^{-1}\right.$ of lactate [18]). The highest plasma lactate concentration in our study was, however, no more than $1.63 \mathrm{mmol} \cdot \mathrm{L}^{-1}$. On the other hand, ISO increased plasma glucose and insulin (figure 2), which may inhibit NEFA release by AT [44], since the plasma antilipolytic concentrations of glucose and insulin in sheep were above $3.5 \mathrm{mmol} \cdot \mathrm{L}^{-1}$ [9] and $4.5 \mathrm{mIU} \cdot \mathrm{L}^{-1}$ [37], respectively. Thus, the net lipolytic effect of ISO would be even greater than that observed, and the real difference between the effects of ISO, D and T on fat mobilisation could be greater than those suggested by our results.

\subsection{Effect of the feeding level on body fat mobilisation}

Underfeeding increased basal plasma NEFA in ruminants, as previously described $[7,15,22]$. This increase in fat mobilisation was not due to a decrease in the antilipolytic effects of basal (preprandial) plasma insulin and glucose [44], because these two factors were not modified in our study (figure 2). However, post-prandial plasma insulin could have been modified by energy level [14].

Basal or ISO-stimulated plasma NEFA levels obtained with the medium diet were in between the levels obtained with the low and high diets (figure 1). This confirms the relationship that exists between basal NEFA or NEFA response to a $\beta$-adrenergic challenge, and energy balance in ruminants $[1,6$, 20]. This increase seems to be due in part to an increase in $\beta 2$-AR stimulation, without changes in the $\beta 1$-adrenergic response. This result contrasts with that of Barbe et al. [2] who reported that the in situ lipolytic response to $\beta 1$-A (dobutamine) was higher than the response to $\beta 2$-A (terbutaline) after a hypocaloric diet in obese humans. Moreover, the in vitro maximal lipolytic responses to $\mathrm{D}$ and $\mathrm{T}$ were not modified after a hypocaloric diet in obese women [25]. The 
increases in the $\beta$ - and $\beta 2$-adrenergic responses after underfeeding in our study could be due to an increase in the number or affinity of $\beta 1$ - and/or $\beta 2-A R$. It has been shown that, in lactating cows, fasting for 3 days increased affinity, but decreased the number of AT $\beta$-AR [26]. Another possibility is that underfeeding increases the coupling efficiency between the $\beta$-AR and adenylyl cyclase or changes other elements of the lipolytic cascade, since there was a decrease in the antilipolytic effect of adenosine in lactating cows fasting over a period of 3 days [26].

Another explanation could be that underfeeding induces an insulin resistance or increases the concentration of other plasma hormones (e.g. growth hormone, glucocorticoids or thyroid hormones), changes which can increase lipolysis and/or potentiate the effects of catecholamines $[10,14,15]$. Glucocorticoids enhance $\beta 2-\mathrm{AR}$ expression, whereas they strongly suppress $\beta 1$ - and $\beta 3-A R$ in murine 3T3-F442A cells [42]. Therefore, glucocorticoids could be partly responsible for the increase in $\beta$ - and $\beta 2$ adrenergic lipolysis in our study.

Basal fat mobilisation was unchanged by medium-term (4 weeks) undernutrition after the initial increase within week 1. A similar result was observed in ewes that were underfed for 4 weeks [15]. This contrasts, however, with Reid and Hinks' [38] and Jackson and Winkler's [28] data on sheep. Indeed these authors observed that plasma NEFA tended to decrease after 3 weeks of underfeeding or fasting.

To our knowledge, there are no published data on the effects of 4-week underfeeding on fat mobilisation response to a $\beta$-A stimulation in ruminants or monogastrics. Plasma NEFA levels after ISO injection were similar after 1 or 4 weeks of underfeeding (figure 1), suggesting that the cattle AT response to $\beta$-adrenergic hormones does not change, and that there is no desensitisation during medium-term underfeeding. It was observed in humans that the sensi- tivity of adipocytes to the antilipolytic effect of adenosine does not change during 4 weeks of energy restriction [29].

This study suggests that lipomobilisation is not coupled with $\beta 1$-AR in cattle, contrary to several other species. Underfeeding rapidly increases the in vivo lipolytic response to $\beta$-A (within 1 week) until it reaches a constant value for at least 4 weeks, and this response is due in part to $\beta 2$-AR stimulation. Additional in vivo and in vitro studies using ISO and selective $\beta 1$ - and $\beta 2$ antagonists are required in order to better understand the effect of changes in feeding levels on the different $\beta$-AR subtypes that regulate lipolysis in cattle.

\section{ACKNOWLEDGEMENTS}

The authors thank M. Berlan and J. Galitzky for their helpful discussions on the experimental protocol, A. Ollier and J.P. Pezant for the management of the animals, D. Thomas, E. Girard and G. Sauvage for blood sample collection, R. Lefaivre and M. Tourret for technical assistance, C. Durier for help in the statistical analysis, P. Béraud and Y. Fournier for help in preparing the manuscript and A.-M. Wall for revising the manuscript. This work was supported by a grant from the Auvergne Region ('Physiological adaptation of animals to harsh environmental conditions' Programme).

\section{REFERENCES}

[1] Barbe P., Millet L., Galitzky J., Lafontan M., Berlan M., In situ assessment of the role of the $\beta 1-, \beta 2$ - and $\beta 3$-adrenoceptors in the control of lipolysis and nutritive blood flow in human subcutaneous adipose tissue, $\mathrm{Br}$. J. Pharmacol. 117 (1996) 907-913.

[2] Barbe P., Stich V., Galitzky J., Kunesova M., Hainer V., Lafontan M., In vivo increase in adrenergic lipolytic response in subcutaneous adipose tissue of obese subjects submitted to a hypocaloric diet, J. Clin. Endocrin. Metabol. 82 (1997) 63-69.

[3] Bareille N., Faverdin P., Lipid metabolism and intake behavior of dairy cows: effects of intravenous lipid and $\beta$-adrenergic supplementation, J. Dairy Sci. 79 (1996) 1209-1220. 
[4] Barnouin J., El Idilbi N., Chilliard Y., Chacornac J.P., Lefaivre R., Micro-dosage automatisé sans déproténisation du 3-hydroxy-butyrate plasmatique chez les bovins, Ann. Rech. Vét. 17 (1986) 129-139.

[5] Bergmeyer H.U., Methods of Enzymatic Analysis, 2nd English ed., Translated from the 3rd German ed., Verlag chimie, Weinheim, Germany, 1974.

[6] Blum J.W., Flueckiger N., Early metabolic and endocrine effects of perorally administered betaadrenoceptor agonists in calves, Eur. J. Pharmacol. 151 (1988) 177-187.

[7] Blum J.W., Fröhli D.M., Kunz P., Effects of catecholamines on plasma free fatty acids in fed and fasted cattle, Endocrinology 110 (1982) 452-456.

[8] Bousquet-Mélou A., Galitzky J., Moreno M.C., Berlan M., Lafontan M., Desensitization of $\beta$-adrenergic responses in adipocytes involves receptor subtypes and cAMP phosphodiesterase, Eur. J. Pharmacol. 289 (1995) 235-247.

[9] Brockman R.P., Effect of glycemic changes on lipolysis in sheep in vivo, Metabolism 33 (1984) 329-331.

[10] Brockman R.P., Laarveld B., Hormonal regulation of metabolism in ruminants: a review, Livestock Prod. Sci. 14 (1986) 313-334.

[11] Casteilla L., Muzzin P., Revelli J.P., Ricquier D., Giacobino J.P., Expression of $\beta 1$ - and $\beta 3$-adrenergic-receptor messages and adenylate cyclase $\beta$-adrenergic response in bovine perirenal adipose tissue during its transformation from brown into white fat, Biochem. J. 297 (1994) 93-97.

[12] Chilliard Y., Bauchart D., Barnouin J., Determination of plasma non esterified fatty acids in herbivores and man: a comparison of values obtained by manual or automatic chromatographic, titrimetric, colorimetric and enzymatic methods, Reprod. Nutr. Dev, 24 (1984) 469-482.

[13] Chilliard Y., Rémond B., Agabriel J., Robelin J., Vérité R., Variations du contenu digestif et des réserves corporelles au cours du cycle gestation-lactation, Bull. Tech. C.R.Z.V. Theix 70 (1987) 117-131.

[14] Chilliard Y., Doreau M., Bocquier F., Lobley G.E., Digestive and metabolic adaptations of ruminants to variations in food supply, in: Journet M., Grenet E., Farce M.H., Thériez M., Demarquilly C. (Ed.), Recent Developments in the Nutrition of Herbivores, Proceedings of the IVth International Symposium on the Nutrition of Herbivores, Inra, Paris, 1995, pp. 329-360.

[15] Chilliard Y., Bocquier F., Doreau M., Digestive and metabolic adaptations of ruminants to undernutrition, and consequences on reproduction, Reprod. Nutr. Dev. 38 (1998) 131-152.

[16] Chilliard Y., Ferlay A., Desprès L., Bocquier F., Plasma non-esterified fatty acid response to a $\beta$-adrenergic challenge in underfed or overfed, dry or lactating cows, before or after feeding, Anim. Sci. 67 (1998) 213-223.

[17] Coppack S.W., Jensen M.D., Miles J.M., In vivo regulation of lipolysis in humans, J. Lipid Res. 35 (1994) 177-193.

[18] De Pergola G., Cignarelli M., Nardelli G., Garruti G., Corso M., Di Paolo S., Cardone F., Giorgino R., Influence of lactate on isoproterenol-induced lipolysis and $\beta$-adrenoceptors distribution in human fat cells, Horm. Metabol. Res. 21 (1989) 210-213.

[19] Ferlay A., Chilliard Y., Effects of $\beta-, \beta_{1}^{-}$, and $\beta_{2}$-adrenoceptor agonist infusion on plasma nonesterified fatty acids in non-pregnant, non-lactating, underfed cows, Ann. Zootech. 44 (1995) 299.

[20] Ferlay A., Chilliard Y., Sala A.M., Durier C. Bocquier F., Somatotropin treatment does not affect non-esterified fatty acid response to adrenergic injections in underfed or overfed nonlactating cows, J. Nutr. 126 (1996) 945-954.

[21] Ferlay A., Charret C., Galitzky J., Berlan M., Chilliard Y., Effects of the infusion of $\beta$-, $\beta 2$ - or $\beta 3$-adrenergic agonists or epinephrine on in situ lipolysis in ewe subcutaneous adipose tissue, Reprod. Nutr. Dev. 38 (1998) 196-197.

[22] Fröhli D.M., Blum J.W., Non-esterified fatty acids and glucose in lactating dairy cows: diurnal variations and changes in responsiveness during fasting to epinephrine and effects of betaadrenergic blockade, J. Dairy Sci. 71 (1988) 1170-1177.

[23] Galitzky J., Langin D., Verwaerde P., Montastruc J.L., Lafontan M., Berlan M., Lipolytic effects of conventional $\beta 3$-adrenoceptor agonists and of CGP 12,177 in rat and human fat cells: preliminary pharmacological evidence for a putative $\beta 4$-adrenoceptor, Br. J. Pharmacol. 122 (1997) 1244-1250.

[24] Germack R., Starzec A.B., Vassy R., Perret G.Y., $\beta$-adrenoceptor subtype expression and function in rat white adipocytes, $\mathrm{Br}$. J. Pharmacol. 120 (1997) 201-210.

[25] Hellström L., Reynisdottir S., Langin D., Rössner S., Arner P., Regulation of lipolysis in fat cells of obese women during long-term hypocaloric diet, Int. J. Obesity 20 (1996) 745-752.

[26] Houseknecht K.L., Bauman D.E., Carey G.B., Mersmann H.J., Effect of bovine somatotropin and food deprivation on $\beta$-adrenergic and Al adenosine receptor binding in adipose tissue of lactating cows, Domest. Anim. Endocrinol. 12 (1995) 325-336.

[27] Institut national de la recherche agronomique (Inra), Jarrige R. (Ed.), Ruminant Nutrition. Recommended Allowances and Feed Tables, John Libbey Eurotext, London, UK, Paris, 1989.

[28] Jackson H.D., Winkler V.W., Effects of starvation on the fatty acid composition of adipose tissue and plasma lipids of sheep, J. Nutr. 100 (1970) 201-207. 
[29] Kather H., Wieland E., Fisher B., Schlierf G., Antilipolytic effects of N6-phenylisopropyladenosine and prostaglandin E2 in fat-cells of obese volunteers before and during energy restriction, Biochem. J. 231 (1985) 531-535.

[30] Lafontan M., Differential recruitment and differential regulation by physiological amines of fat cell $\beta 1, \beta 2$ et $\beta 3$-adrenergic receptors expressed in nature fat cells and in transfected cell lines, Cell. Signal. 6 (1994) 363-392.

[31] Lafontan M., Berlan M., Prud'hon M., Les agonistes bêta-adrénergiques. Mécanismes d'action: lipomobilisation et anabolisme, Reprod. Nutr. Dev. 28 (1988) 61-84.

[32] Lafontan M., Bousquet-Mélou A., Galitzky J., Barbe P., Carpéné C., Langin D., Berlan M., Valet P., Castan I., Bouloumié A., SaulnierBlache J.S., Adrenergic receptors and fat cells: differential recruitment by physiological amines and homologous regulation, Obesity Res. 3 (1995) 507S-514S.

[33] Mauriège P., De Pergola G., Berlan M., Lafon$\tan$ M., Human fat cell beta-adrenergic receptors: beta-agonist-dependent lipolytic responses and characterization of beta-adrenergic binding sites on human fat cell membranes with highly

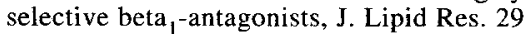
(1988) 587-601.

[34] McGowan M.V., Artiss J.D., Strandbergh D.R., Zak B., A peroxidase-coupled method for the colorimetric determination of serum triglycerides, Clin. Chem. 29 (1983) 538-542.

[35] Mersmann H.J., Specificity of $\beta$-adrenergic control of lipolysis in swine adipose tissue, Comp. Biochem. Physiol. 77C (1984) 39-42.

[36] Metz S.H.M., Van de Bergh S.G., Effects of volatile fatty acids, ketone bodies, glucose and insulin on lipolysis in bovine adipose tissue, FEBS Lett. 21 (1972) 203-206.
[37] Petterson J.A., Slepetid R., Ehrhardt R.A., Dunshea F.R., Bell A.W., Pregnancy but not moderate undernutrition attenuates insulin suppression of fat mobilization in sheep, J. Nutr. 124 (1994) 2431-2436.

[38] Reid R.L., Hinks N.T., Studies on the carbohydrate metabolism of sheep. XIX The metabolism of glucose, free fatty acids, and ketones bodies after feeding and during fasting or undernourishment of non-pregnant, pregnant, and lactating ewes, Aust. J. Agric. Res. 13 (1962) 1124-1136.

[39] SAS User's Guide: Statistics, Version 6 Edition, Statistical Analysis Systems Institute, Inc., Cary, NC, USA. 1987.

[40] Shimojo N., Naka K., Nakajima C., Yoshikawa C., Okuda K., Okada K., Test-strip method for measuring lactate in whole blood, Clin. Chem. 35 (1989) 1992-1994.

[41] Sillence M.N., Matthews M.L., Classical and atypical binding sites for $\beta$-adrenoceptor ligands and activation of adenylyl cyclase in bovine skeletal muscle and adipose tissue membranes, Br. J. Pharmacol. 111 (1994) 866-872.

[42] Strosberg A.D., Structure and function of the $\beta_{3}$-adrenergic receptor, Annu. Rev. Pharmacol. Toxicol. 37 (1997) 421-450.

[43] Van Liefde I., Van Ermen A., Van Witzenburg Fraeyman A., Vauquelin G., Species and strainrelated differences in the expression and functionality of $\beta$-adrenoceptor subtypes in adipose tissue, Arch. Int. Pharmacol. Thérapie 327 (1994) 69-86.

[44] Vernon R.G., Effects of diet on lipolysis and its regulation, Proc. Nutr. Soc. 51 (1992) 397-408.

[45] Webber J., McDonald I.A., Metabolic actions of catecholamines in man, Baillières Clin. Endocrinol. Metab. 7 (1993) 393-413. 